\title{
CDISC System Organ Class
}

National Cancer Institute

\section{Source}

National Cancer Institute. CDISC System Organ Class. NCI Thesaurus. Code C64388.

Terms at the highest level of the CDISC system org an class terminology. 